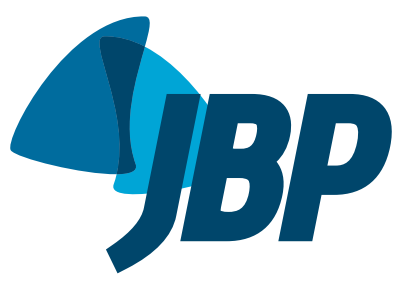

1. Pavilhão Pereira Filho, Santa Casa de Misericórdia de Porto Alegre, Porto Alegre (RS) Brasil.

2. Núcleo de Estudos e Tratamento do Tabagismo, Instituto de Doenças do Tórax, Universidade Federal do Rio de Janeiro, Rio de Janeiro (RJ) Brasil.

3. Hospital São Julião, Campo Grande (MS) Brasil.

4. Hospital de Messejana, Fortaleza (CE) Brasil.

5. Hospital do Servidor Público Estadual de São Paulo, São Paulo (SP) Brasil.

\section{Submitted: 8 May 2016.}

Accepted: 7 July 2016

Study carried out by the Comissão de Tabagismo, Sociedade Brasileira de Pneumologia e Tisiologia - SBPT - Brasília (DF) Brasil.

\title{
Smoking control: challenges and achievements
}

\author{
Luiz Carlos Corrêa da Silva', Alberto José de Araújo², \\ Ângela Maria Dias de Queiroz ${ }^{3}$, Maria da Penha Uchoa Sales ${ }^{4}$, \\ Maria Vera Cruz de Oliveira Castellano ${ }^{5}$; Comissão de Tabagismo da SBPT
}

\begin{abstract}
Smoking is the most preventable and controllable health risk. Therefore, all health care professionals should give their utmost attention to and be more focused on the problem of smoking. Tobacco is a highly profitable product, because of its large-scale production and great number of consumers. Smoking control policies and treatment resources for smoking cessation have advanced in recent years, showing highly satisfactory results, particularly in Brazil. However, there is yet a long way to go before smoking can be considered a controlled disease from a public health standpoint. We can already perceive that the behavior of our society regarding smoking is changing, albeit slowly. Therefore, pulmonologists have a very promising area in which to work with their patients and the general population. We must act with greater impetus in support of health care policies and social living standards that directly contribute to improving health and quality of life. In this respect, pulmonologists can play a greater role as they get more involved in treating smokers, strengthening anti-smoking laws, and demanding health care policies related to lung diseases.
\end{abstract}

Keywords: Tobacco products; Smoking; Health policy; Smoking cessation; Health personnel.

\section{INTRODUCTION}

The primary objective of the present article was to offer, particularly to pulmonologists, smoking-related information that can aid in the daily practice of delivering care to smoking patients at the medical office.

Since the middle of last century in Brazil, some pulmonologists have called attention to the health hazards of smoking, and this at a time when pro-tobacco media messages were overt and the scientific evidence on the causes of such hazards was inconsistent. They devoted themselves to the cause of smoking cessation as true champions of health, hacking their way through a jungle infested with ignorance, commercial interests, tax greed, pro-tobacco media messages, and also the social acceptability of smoking. In honoring José Rosemberg and Mario Rigatto, we pay tribute to all.

The Sociedade Brasileira de Pneumologia e Tisiologia (SBPT, Brazilian Thoracic Association) Commission on Smoking started its representative activities in 2000 and, thanks to the work of its members, has made the SBPT one of the most active and respected Brazilian institutions in this sector. It participated in the major initiatives that resulted in the enactment of the Anti-Smoking Law (Brazilian Federal Law no. 12,546/2011), (1) in partnership with governmental and non-governmental entities: the Brazilian National Ministry of Health Instituto Nacional do Câncer (INCA, National Cancer Institute); the Comissão Nacional para Implementação da Convenção-Quadro para o Controle do Tabaco (CONICQ, Brazilian National
Commission for Implementation of the Framework Convention on Tobacco Control); the Aliança de Controle do Tabagismo + Saúde (ACT+, Alliance for the Control of Smoking + Health); the Associação Médica Brasileira (AMB, Brazilian Medical Association); and the Brazilian Federal Medical Council. Through the "Letter from Gramado", issued during the Brazilian Pulmonology Conference held in that Brazilian city in 2014, the position of the SBPT regarding smoking became more strongly consolidated. ${ }^{(2)}$

Differential characteristics of the SBPT regarding smoking include its active leadership, pulmonologist training programs in treating smokers, the dissemination of the concept that "smoking is a treatable disease", and ongoing initiatives for the development of policies for the control of this pandemic.

Some important facts have underpinned the successive initiatives undertaken in recent decades to control smoking. The large study by Doll et al.,(3) involving a cohort of 35,000 British physicians, followed for more than five decades, effectively showed the hazards caused by smoking, particularly the remarkable increase in the prevalence of lung cancer. In addition, there is the huge set of information that has been obtained in recent decades and that invariably points to unequivocal evidence on the risks and hazards of smoking. In the USA, a ruling by Judge Gladys Kessler, ${ }^{(4)}$ who compiled a large dossier on the consequences of smoking and the fraudulent strategies employed by the tobacco industry (TI), resulted in US tobacco companies being sentenced to pay billions of dollars. The development of the Framework

Correspondence to:

Luiz Carlos Corrêa da Silva. Rua Pedro Ivo, 532/302, Mont'Serrat, CEP 90450-210, Porto Alegre, RS, Brasil.

Tel.: 5551 9991-0974 or 5551 3221-8522. E-mail: Iccsilva@yahoo.com.br

Financial support: None. 
Convention on Tobacco Control (FCTC), ${ }^{(5)}$ the first and largest international public health treaty negotiated by the World Health Organization (WHO), in 2005, was a milestone in the control of this pandemic with devastating consequences. In Brazil, the key role of the initiatives and interventions of the INCA, ${ }^{(6)}$ the CONICQ, ${ }^{(7)}$ and the $A C T+{ }^{(8)}$ is of note, as is that of medical organizations.

Since tobacco production and sales, mainly in the form of cigarettes, remain a component of the State's economic policy and tobacco consumption remains a component of society's everyday life, bringing huge economic gains to the industry and its shareholders, there remains an enormous power that ensures the survival of this sector.

Analysis of such a scenario leads to the conclusion that there will be little progress beyond our current state, at least within the desired time frame, if serious initiatives are not undertaken to fight the TI, especially regarding its interference in the implementation of the health policies recommended by the FCTC.

The health argument will not be strong enough to ban tobacco, a drug that is produced and distributed legally, and, therefore, smoking will still continue in this century and will probably reach the 22nd century. In addition to tobacco control and education policies, there is a need for other ways to act and strengthen the network, which will make it possible for future generations to wipe this pest off the face of the earth.

It will be indispensable to tax the leaf export prices and the sales of other tobacco products exemplary. In addition, taxes should be established by law in order to meet the public health system and social security expenditures for tobacco-related diseases. Furthermore, it is urgent that all those involved, from an economic standpoint, in the tobacco supply chain be punished by justice for the harm they have caused to tobacco victims, an event rarely seen in Brazil.

Let us analyze some issues from the standpoint of the TI. The major motivation and strength of the TI, which is also its Achilles' heel, are its positive financial results. The TI buys political support by providing funds and resources to election campaigns, by covering the needs of opportunist people and groups, and by exchanging benefits with other sectors. The TI very well knows how to maneuver the so-called fragile sectors, such as the family agriculture sector, which still is highly dependent on tobacco cultivation. In addition, the TI relies on the vulnerability of smokers, who, because they are dependent, cannot deal rationally with this risk factor for their health and life. If legal readings are up to date, correct, and impartial and the TI has to pay millions of dollars in compensation for harm caused to tobacco users, the TI certainly will not be able to stay in business.

Let us consider the standpoint of activists and governmental and non-governmental groups and organizations devoted to tobacco and smoking control. The government support has been feeble, although there has been a state policy (embodied in law) ratifying the FCTC since 2005. Unfortunately, as a rule, the government only thinks of the immediate revenues generated by taxes, revenues that in fact are much lower than the expenditures for tobacco-related diseases. In addition, the TI, through effective lobbying strategies, has secured support from distinguished representatives of various spheres of government, all of whom defend its corporate rights. Rarely do political leaders take a firm stand and affirm their decisions regarding the implementation of laws that are more restrictive of tobacco consumption or regarding diversification of tobacco cultivation. Some exceptions include Uruguay's President Tabaré Vázquez, an oncologist, in 2003; former New York Mayor Michael Bloomberg, a philanthropist, in 2005; and former São Paulo State Governor José Serra, an economist, in 2009. Although there have been many anti-tobacco achievements, they often become fragmented and discontinuous, and maintaining them is difficult and laborious given the fire power of the TI, which is always on the alert and relies on many lobbyists and other pressure groups, usually linked to trade associations of bars, restaurants, hotels, and bakeries, that act as "façade groups" defending the interests of the TI. Networking has been very efficient and important for the continuity of initiatives and should be encouraged and increased, despite the fact that maintaining it is very exhausting.

For the purpose of networking, partnerships should be established with institutions that are interested in the topic and have members with ability to foster teamwork, in order to devise strategies that are stronger and will attract more followers and more leaders, particularly those working with civil society and those with political influence.

Everything that has been achieved should be maintained-and there have been no few advances in Brazil-however, compensation claims for harm suffered by citizens should be particularly encouraged as consistently as possible. To that end, there is now an instrument devised by the AMB, the ACT+, and other institutions, among which is the SBPT: an AMB guideline called "Evidências Científicas sobre Tabagismo para Subsídio ao Poder Judiciário" (Scientific Evidence on Smoking for Use by the Judiciary). ${ }^{(9)}$ This guideline needs to be incorporated into practice and used as a reference by the justice sector in the analysis of such claims.

Below, we address some topics considered of particular importance, with which pulmonologists need to be familiar and which they need to explore further with a view to their practice and to their contribution to smoking control.

\section{CONCEPTS}

For over two decades, smoking has been considered to be a neurobehavioral disorder caused by nicotine dependence. ${ }^{(10)}$ In addition, there are numerous other factors, especially behavioral and psychological ones, 
that induce smoking and therefore hinder smoking cessation. Anxiety, depression, disorders of various natures, psychiatric problems, low self-esteem, automatisms, triggers, and customs, as well as psychosocial, cultural, and genetic factors, are inducers. In contrast, reproaches, restrictive pressures, anti-smoking laws, etc. are smoking control measures. It is necessary to understand that people smoke because they are dependent and not just because they want to. ${ }^{(9)}$

Smoking, in addition to being a chronic disease caused by nicotine dependence, is one of the major risk factors for diseases and high mortality. Contrary to what was advertised for years, smoking is not a lifestyle choice, a sign of charm, a sociability factor, or an expression of choice or free will, nor does it bring economic advantages to the government or to society. ${ }^{(11)}$

\section{CONSEQUENCES OF SMOKING}

According to data from the $\mathrm{WHO}^{(12)}$ the major causes of human mortality, accounting for more than $68 \%$ of deaths, are chronic noncommunicable diseases, many of which are tobacco-related: cardiovascular disease (particularly acute myocardial infarction); cancer (in the lung and in other sites); stroke, and COPD. By not smoking or by quitting smoking, you can reduce the risk of developing these diseases by more than $30 \%$, with reductions being as high as $90 \%$ for lung cancer and for COPD. Nonsmokers have a better quality of life and live 10 to 15 years longer. ${ }^{(13)}$ One of the consequences of passive smoking, that is, cardiovascular damage, was studied by Lightwood \& Glantz, who found that, after the implementation of smoke-free environments in several countries, there was a nearly $30 \%$ reduction in acute cardiac events in the short term. ${ }^{(14)}$

It has recently been shown that the harmful effects of tobacco are transmitted across generations, increasing the risk of asthma intergenerationally, that is, from mother to son, and transgenerationally, that is, from grandparents to grandchildren, even if the mother does not have asthma and does not smoke. There is evidence that the smoking of the maternal grandmother while pregnant with the mother increases the risk of asthma development in the grandchild by two to three times, even if the mother did not smoke during pregnancy and does not have asthma. ${ }^{(15)}$

The American Cancer Society has released a report on smokers who are dying from diseases hitherto considered unrelated to tobacco. ${ }^{(16)}$ Fourteen additional diseases were associated with smoking: breast cancer; prostate cancer; renal failure; intestinal ischemia; arterial hypertension; and infections; as well as several other respiratory diseases in addition to COPD. This resulted in an increase of $17 \%$ in mortality.

\section{SMOKING TREND}

In developed countries and in some developing countries, a marked reduction in the prevalence of smoking has been achieved. However, in the world as a whole, this prevalence is increasing, particularly in countries with low economic resources and in poorer and less educated populations. In 2014, there were six million deaths from tobacco-related diseases, and, by 2030 , this figure could reach eight million if nothing of great impact is done to control the pandemic. ${ }^{(17)}$

Since the 1980s, Brazil has been noteworthy for developing progressively more effective control policies, which has reduced the prevalence of smoking in the adult population from $35 \%$ in $1989^{(18)}$ to $14.7 \%$ in $2013 . .^{(19)}$

Although there are more than 26 million former smokers in Brazil, since many people have quit smoking on their own or with treatment, there are still 22 million smokers who need treatment. These "residual smokers" may have more difficulty in quitting smoking, whether because they have greater nicotine dependence, behavioral disorders, or psychiatric disorders or because of other factors hindering cessation, among which are genetic, social, and environmental factors. This large group has yet to be properly studied.

The TI, in turn, always develops new strategies and tricks to sell its products. Electronic cigarettes, waterpipe tobacco smoking, smokeless tobacco (snus), and new nicotine delivery devices need to be controlled and contained, under penalty of losing the ground gained in smoking control. The TI and its shareholders have great expectations for this new vein of the market, since these products have led most users to believe-by misinformation and manipulation through strong advertising campaigns-that they are harmless and do not cause the health hazards known to be associated with the traditional forms of smoking (cigarettes, cigars, and pipes).

Forecasts by insurance entities indicate such an exponential growth with the explosion in electronic cigarette sales that these sales may surpass conventional cigarette sales in a few decades. Initiation of the use of these electronic nicotine delivery devices has reached a reasonable portion of the population. The total volume of conventional cigarettes sold, accounting for US\$85 billion in retail sales, has been declining at an annual rate of $3-4 \%$. (20) In recent years, the decline has accelerated, mainly because of the ban on indoor smoking, health concerns, pricing policies, and other government regulations resulting from the WHO FCTC. ${ }^{(6)}$ It is estimated that electronic cigarette sales will grow exponentially between 2015 and 2023, and that, by 2022, electronic cigarette sales will surpass conventional cigarette sales and will continue on a upward curve. ${ }^{(21)}$ Therefore, after 140 years of dominance of paper-wrapped cigarettes, which began with the invention of the Bonsack cigarette rolling machine, in 1880 , electronic cigarettes will take the role of villain in the 21 st century.

\section{ANTI-SMOKING LAW}

Brazilian Federal Law no. 12,546/2011,(1) which has been in effect since December of 2014, must be known 
and respected by all and must be properly enforced by the entitled authority, particularly the health oversight sector. This law contains items of practical relevance, such as a ban on smoking indoors (with indoors being defined as covered areas, side walled areas, places with awnings, outdoor decks at bars and restaurants, bus stops, etc.), a ban on designated smoking areas, price increase policies, a ban on advertising at sales points, and warning labels covering one third of the face of the cigarette pack. The back of the cigarette pack will continue to display the usual warnings.

\section{SMOKING CONTROL STRATEGIES}

\section{Prevention}

It is essential to prevent youths from experimenting with cigarettes, because, if they do experiment, they will have a greater than $50 \%$ chance of becoming dependent. What should be done? Education; family control and school control; and enforcement of anti-smoking laws, particularly a ban on the sale of tobacco products to minors and other initiatives aimed at youths. ${ }^{(21)}$

\section{Protection}

The population should be protected from the effects of environmental tobacco smoke and from the influences that lead to smoking, particularly those related to the circle of family, friends, and colleagues. Anti-smoking laws, which, among other rules, ban smoking in public places, should be rigorously enforced. ${ }^{(21)}$

\section{Treatment}

Treatment should be offered to all smokers who are unable to quit smoking on their own initiative and wish to quit smoking. The cost-effectiveness of treatment is highly favorable, because, when people quit smoking, they live 10-15 years longer and have a better quality of life and there is a $30-90 \%$ reduction in the occurrence of chronic, tobacco-related noncommunicable diseases. In addition, former smokers serve as an example and stimulus for those who still smoke. ${ }^{(21)}$

The coverage and scope of such interventions can vary, but it is known that, among the population of smokers in Brazil, which comprises 22 million people, less than $5 \%$ receive treatment provided by the Brazilian National Ministry of Health. In contrast, the Anti-Smoking Law, in one way or another, reaches the entire population and therefore, directly or indirectly, has a coverage of $100 \%$. Establishing environments free of tobacco smoke is the most effective measure for controlling smoking in the community. Increasing prices also achieves significant results, since a $10 \%$ increase in prices leads to a $4 \%$ decrease in consumption. ${ }^{(22)}$

\section{MULTIPLYING NETWORKS}

The only way to fight and overcome this pandemic that affects 1.3 billion people worldwide is to create a large network that can bring together as many institutions and people as possible. The WHO, given its experience, its political status, and its worldwide leadership role advocating for the FCTC, formally unites this global network through the conference of the parties. In Brazil, the National Ministry of Health (through the INCA), nongovernmental organizations (such as the ACT+), medical organizations (such as the SBPT), and other local state and municipal institutions develop their control programs based on the FCTC guidelines.

It is of note that the FCTC has recently celebrated its 10th anniversary, and the results show that its smoking control goals have been achieved in the 180 countries that have ratified the treaty and that are adapting or formulating their policies and laws according to national characteristics.

\section{SMOKING TREATMENT PROGRAM}

This topic is based on several references. ${ }^{(11,23-26)}$ The initial planning of treatment should always take into account the reality of the patients' world, their sociocultural profile, behavioral aspects, beliefs, taboos, other types of dependence, and, especially, their level of motivation to quit smoking and their level of nicotine dependence. It should be defined whether an individual program, a group program, or a mixed program is the most appropriate.

Treatment duration should be no less than three months, but it can vary greatly depending on the individual situation and the physician-patient relationship.

\section{First phase of the program (intensive, aimed at cessation)}

Consultations should occur weekly in the first month. In the first consultation, personal aspects, history of smoking, level of motivation, and level of dependence should be assessed, as should respiratory symptoms and other types of symptoms. Assessment tests (e.g., chest X-ray and spirometry) should be requested as necessary, if possible. The whole program should be explained to patients, with emphasis on the four basic steps: (1) wanting to (having desire and motivation); (2) preparing oneself (with technical support, cognitive behavioral therapy [CBT], and, if necessary, medications); (3) setting D-Day (the cessation day; this will create an objective commitment); and (4) maintaining abstinence (relapse prevention)

In the second consultation, the test results should be assessed, the required data should be collected, and the program should be explained in more detail. The CBT items that apply to individual cases, particular those related to motivation and to the necessary behavioral changes, should be emphasized. The other CBT items that should be addressed are smoking cessation objectives, smoking cessation benefits, triggers, frustrations, automatic mechanisms, reward mechanisms, ambivalence, and how to cope with the most common causes of relapse (a coping plan). 
The need for medication prescription should be assessed, and, that being the case, the most appropriate treatment regimen should be chosen. D-Day should be set. It can be the day preferred by the patient: his or her own birthday; the birthday of a family member or friend; or any other relevant date. It is important that D-Day be within the next three weeks, in order to prevent a delay in decision that would discourage the patient from pursuing the set goal. The primary objective of the program is that D-Day will happen.

Drug therapy is aimed at reducing the symptoms of smoking withdrawal syndrome. CBT is aimed at aspects that greatly affect smoking cessation and maintenance of abstinence: psychological dependence; anxiety; depression; psychosocial aspects; low self-esteem; automatisms; and triggers.

\section{Second phase of the program (maintenance, aimed at preventing relapse)}

After cessation, treatment should focus on preparing patients for challenges that often arise and frequently lead to lapses and relapses. Although it is thought that, after a year of abstinence, the worst has passed, patients should be constantly on their guard, since, even after many years, they may feel the urge to smoke and may relapse. It should be emphasized to patients that, when faced with any difficulty, they should maintain abstinence and, as soon as possible, have a consultation with or contact their physician or someone in the team in order not to affect treatment negatively.

\section{RELAPSE}

Fear of relapse or relapse itself needs to be handled objectively. Patients need to know that many smokers only manage to quit smoking successfully after the umpteenth attempt. On average, five quit attempts are needed. If patients relapse, they should return to the program and, with technical support, review and correct what went wrong. Persistence is what matters. Retreatment may require previously unused resources, such as a combination of several medications, CBT reinforcement, and, obviously, greater attention and commitment of patients and physicians.

\section{REMOTE AID FOR SMOKERS}

Information and communication technologies can potentially be combined with the advantages of intensive treatments, which are more individualized, and with far-reaching interventions, through incorporation of interactive responses, by adapting personal contact strategies. Studies have highlighted the considerable potential of social networks for promoting the adoption of healthier behaviors, including smoking cessation. Web-based projects that enable social support through forums, e-mails, and chat rooms have resulted in a three-fold increase in the chance of success of motivated smokers struggling to overcome smoking in the first three months. ${ }^{(27-30)}$
In Brazil, there is a computer application called TratBem, ${ }^{(28)}$ which has been developed to assist patients in the different stages of changing habits, by providing social, informative, and psychological support through automatic or individualized messages. Different messages can be sent to different patients depending on the number of days left to D-Day or after the quit date. During cravings, patients can send messages and receive support directly from the application, through messaging from a support team professional or their own support network. It is important to emphasize that low-income people can benefit from this application, using only text messages. This support resource for smokers going through the cessation process has been presented and demonstrated in events in the fields of computer science, medical informatics and health. This application enables interaction among patients, family members, friends, and health professionals in a collaborative effort to overcome the smoking addiction. ${ }^{(30)}$

\section{SMOKING AND COPD}

Smoking is the major factor associated with COPD, and its mechanism of action is through an inflammatory cascade involving epithelial cells, macrophages, fibroblasts, and cytokines, such as IL-4, IL-5, TNF-a, etc., which, together with neutrophils and the action of neutrophil elastase, results in alveolar wall destruction, fibrosis of the small airways, and hypersecretion of mucus. This triad is the basis of the major symptoms of COPD: dyspnea; cough; and expectoration. These symptoms cause significant progressive disability, with a rapid deterioration in quality of life and in life expectancy.

In their study, Fletcher \& Peto ${ }^{(31)}$ showed that the rate of lung function loss slows after smoking cessation, even if the cessation occurs at age 65 . Anthonisen et al.,(32) after an 11-year follow-up period, concluded that the patients who continued to smoke had a lower $\mathrm{FEV}_{1}$ than did those who quit smoking.

In an interesting meta-analysis of phase III randomized studies that assessed the effects of bronchodilators and inhaled corticosteroids in COPD patients, conducted by Tonnesen, ${ }^{(33)}$ the prevalence of active smokers ranged from $38 \%$ to $77 \%$. Spirometry is mandatory for patients over 40 years of age who seek smoking cessation treatment. Godoy et al. (34) reported that $30 \%$ of the patients enrolled in a smoking cessation program had COPD.

The calculation of lung age, which, in COPD patients, gives higher values than the chronological age values, can be a motivator for smoking cessation. ${ }^{(35)}$

Patients must be motivated and must have overcome ambivalent feelings about smoking cessation before starting the medication treatment. The same medication protocols used for the general population should be used for smoking patients with COPD. Smoking cessation results in decreased dyspnea, 
slowing of COPD progression, and reduced frequency of exacerbations. ${ }^{(11,35,36)}$

\section{ADVOCACY}

The word advocacy does not have a one-word translation into Portuguese. It could be translated as "the process of positive persuasion of people who have significant decision-making influence in a given sector" or something similar. However, the best definition seems to be "a set of activities that is planned to transform certain conditions with a view to achieving better circumstances and may involve efforts to change perceptions, attitudes, and/or policies, whether written or not".

Leaders of governmental institutions need to be informed with updated objective data on tobacco and smoking. They need to be aware that the days of tobacco leaf exports worth billions are numbered and that the sectors associated with this trade, particularly small farmers, need to be prepared for migration to other crops and for other necessary changes. In addition, they need to know that, of the measures already imposed by the Anti-smoking Law, increasing prices and implementing 100 percent smoke-free environments are the most effective and have the most immediate results.

\section{PULMONOLOGISTS AND THE SBPT IN SMOKING CONTROL}

These considerations extend to all physicians and other health care professionals. Everything begins with personal attitude: they should not smoke; they should be a model of healthy behavior; they should tirelessly advocate 100 percent smoke-free environments; they should take a firm stand against smoking; they should always advise patients not to smoke; and, finally, they should continuously encourage the practice of a healthy lifestyle, which includes smoking prevention and smoking cessation.

In consultations and interactions with patients, the following questions should be asked, at least at the first contact: "Do you smoke?"; "Do you want to quit?"; "How do you intent to do it?"; and "Do you want help?".

A smoking cessation plan should always be proposed to smoking patients, and they should be told with conviction "If you want to quit smoking, you will. Let's find the way together."

The many ways to quit smoking should be taken into account:

- Personal initiative, without specific professional guidance

- A brief intervention, with counseling and monitoring by a physician or another health care professional

- Treatment in accordance with guidelines recommended by referral institutions (INCA, SBPT, American Thoracic Society, and European Respiratory Society), using resources such as CBT and medications (nicotine replacement therapy, nicotine, bupropion, varenicline, etc.), always under medical supervision

- A structured, multidisciplinary treatment program, with the participation of professionals from various fields, using the same resources as the previous modality but relying on the experience of the professionals in their respective areas

The SBPT, through its successive Boards of Directors and the direct involvement of the Commission on Smoking, has been promoting a debate regarding the need for approval of a "Field of Interest", or simply a "Certification in Smoking Cessation", since its First Brazilian Conference on Smoking in 2005. This certification would assist a large number of pulmonologists who work in the treatment of smoking, as well as making it possible for other specialists, such as cardiologists, general practitioners, psychiatrists, and pediatricians, to work in the prevention and treatment of smoking as a certified professional.

Therefore, the SBT has been offering training courses in interventions for smokers during its national, regional and state conferences, as well as in its continuing education programs.

This proposal meets the definition of mode of organization of medical work, performed by professionals trained to perform specific medical activities, being derived from and related to one or more specialties.

The approval of the proposal is warranted because smoking is the leading preventable cause of disease, disability, and death worldwide and in Brazil. In our country, there are approximately 22 million smokers, who generate public expenditures of 21 billion Brazilian reals per year solely on the treatment of diseases related to tobacco consumption. ${ }^{(37)}$

In the latest SBPT proposal submitted to the AMB, there is a basic protocol for an intensive 12-week intervention for smokers, including outpatient clinical assessments and individual and/or group follow-up. The intervention frequency can be weekly or fortnightly, and a limit of seven consultations should not be exceeded. The procedural codes, according to the AMB table, would be as follows: outpatient medical consultation (code 2B); and inpatient medical visit to a smoker who presents with withdrawal syndrome (code $2 A$ ).

The intensive intervention for smoking patients will be a procedure identified with a specific code and does not include consultations for other clinical complications. Since smoking is a disease susceptible to relapse, we must consider for this procedure the need to promote the return of smoking patients to the intensive intervention for a new quit attempt, on the basis of medical reasons.

In the proposal sent by the SBPT, measurement of exhaled carbon monoxide (eCO) was also included, being categorized as code $1 \mathrm{~A}$ (similar to noninvasive oximetry).

Once the creation of a "Certification in Smoking Cessation" is approved, a training and certification program endorsed by the AMB should be put into 
practice so that certified medical professionals can be accredited to work with private and supplemental health insurance plans. The SBPT, which has already been developing courses for pulmonologists, has presented to the AMB a proposal with basic requirements and contents for the training and certification of physicians.

\section{INITIATIVES OF REGIONAL SOCIETIES}

Pulmonologists play an important role in motivating smokers to quit smoking, in guiding therapy, and in the follow-up of patients. Regional societies, as is to be expected, locally reinforce national smoking control campaigns. In order to encourage pulmonologists to act more effectively, regional societies should help them implement interventions for smokers in their private practices, in hospitals, at public health care facilities, and at universities, by establishing partnerships with public and private sectors to organize centers for the prevention and treatment of smoking.

In addition, regional societies should work on the front lines to advise lay public of the harmful effects of smoking, addressing this issue on special dates related to tobacco (World No Tobacco Day, National Day against Tobacco, World COPD Day, World Asthma Day, National Cancer Awareness Day, etc.) through various media vehicles. Events, such as sports competitions and educational activities in shopping centers and supermarkets, should be promoted for lay people in the community. Active participation of regional societies in scientific meetings at symposiums, conferences, and forums is another form of encouragement, given that such meetings set the stage for fruitful discussions regarding smoking, as a way to educate more people, increasing the impact of campaigns focused on gaining the support of opinion leaders for these initiatives. Furthermore, partnerships should be sought with primary and secondary schools, undergraduate medical schools, and residency medical programs.

Last but not least, regional societies should work in conjunction with the various primary care programs in their various areas of complexity (programs to control arterial hypertension, diabetes mellitus, tuberculosis, and leprosy; programs for adolescents; and programs for children), promoting in those areas the behaviors and practices of the smoking cessation intervention, with the aim of providing comprehensive care to the community.

\section{DIAGNOSTIC PROCEDURES THAT CAN BE USEFUL FOR SMOKING CESSATION}

The basic routine recommended in the SBPT Guidelines for Smoking Cessation ${ }^{(26)}$ is to request chest X-ray, pre- and post-bronchodilator spirometry, electrocardiography, a complete blood count, and serum and urine biochemistry. Measurement of eCO and measurement of cotinine (in serum, saliva, or urine) are useful in the assessment and follow-up of smokers and should be used when available. The tests serve as motivators for smoking cessation.
Chest X-ray, depending on the conditions available, can be useful in the smoker protocol, especially for early detection of tobacco-related diseases, such as lung cancer, COPD, and respiratory bronchiolitis. In a randomized clinical trial conducted in Denmark, 4,104 smokers motivated to quit, who were enrolled in a smoking cessation program, were divided into two groups: those undergoing and those not undergoing CT screening for lung cancer. ${ }^{(38)}$ At 1-year follow-up, smoking cessation and relapse rates were similar between the two groups. However, the subgroup of those with initial CT findings requiring a repeat chest CT scan three months later had higher smoking cessation rates and lower relapse rates than did the other subjects. Chest CT is found to have a favorable cost-benefit ratio in the screening of high-risk patients when it is performed using low doses of radiation. In countries with scarce logistics and/or financial resources, low-dose $\mathrm{CT}$ screening referrals will be subject to available resources. ${ }^{(39)}$ It should be taken into account that, when a patient undergoes chest $\mathrm{CT}$, this might mean that there is a health concern, which is a motivator and an opportunity for smoking cessation. ${ }^{(40)}$

Spirometry should be performed whenever possible, because it enables early diagnosis of COPD. In addition, it can aid in determining the patient's "functional age", which can be used to encourage smoking cessation. For instance, after being assessed, the smoking patient can be told the following: "Your lung function should correspond to that expected for your age group, but, on the basis of the observed spirometric values, it is equivalent to that predicted for those 20 years older than you."

Measurement of eCO can be useful primarily to show patients that results above $6 \mathrm{ppm}$ indicate that they are still smoking. During the smoking cessation process, a decrease in eCO levels can greatly influence smokers. A random high measurement can be a means to catch their attention and motivate them to quit smoking. ${ }^{(25,26)}$

\section{ELECTRONIC CIGARETTES AND WATERPIPE TOBACCO SMOKING}

The position of the SBPT on electronic cigarettes is as follows: until robust studies are performed that demonstrate the safety and efficacy of the proposed indications for use, the sale of electronic cigarettes cannot be authorized and they should be subject to the same control regulations as those applied to conventional cigarettes and other smoking products. Likewise, the same control regulations should be applied to waterpipe tobacco smoking and to any other form of smoking that might emerge, given their risks.

There are hundreds of "brands" of electronic cigarettes, which have the most varied characteristics and compositions and which have not been submitted to oversight. Therefore, their regulation will be impossible!

Forms of exposure emerge all the time and proliferate: now there are electronic cigarettes and waterpipe 
tobacco smoking. Both are taking up where conventional cigarettes left off and may undermine the achievements already made in smoking control. They should be seen in the same light as that in which we now view conventional cigarettes. The tobacco companies have already dominated this sector. We wonder why. The loss of profit caused by the reduction in conventional cigarette sales is projected to be replaced by the profit gain from electronic cigarette sales.

\section{FINAL CONSIDERATIONS}

Pulmonologists and all health care professionals need to give maximum attention to smoking patients and to youths who have not yet started smoking, since primary and secondary prevention are priorities. Providing a brief intervention, no matter how short, will already be a significant contribution, since this type of intervention is the most cost-effective one. At the opposite end of the spectrum are pulmonologists with a more focused dedication to smoking cessation, that is, tobacco treatment specialists, who take care of smokers individually or in group, in a multidisciplinary team.

Currently, there are very effective resources for the treatment of smokers, and pulmonologists need to be informed and trained for this purpose. The SBPT Commission on Smoking will always be available to help.

\section{ACKNOWLEDGMENTS}

The authors would like to thank all of those who always collaborate with the SBPT Commission on Smoking, particularly its former coordinators, for their work, and all of those who, even anonymously, contribute to smoking control. We are also grateful to the SBPT directors, who always support and encourage the continuation of the fight against smoking, which is endless. We are especially grateful to the SBPT staff members, who go to great lengths to make it possible for our projects and initiatives to be carried out as promptly as possible and with the highest quality possible.

\section{REFERENCES}

1. Brasil. Presidência da República. Ministério da Casa Civil, Subchefia para Assuntos Jurídicos. Lei $N^{\circ}$ 12.546. Brasília: Diário Oficial da República Federativa do Brasil (Dec 14 2011).

2. Pneumoimagem [homepage on the Internet]. São Paulo: Pneumoimagem [updated 2016 Jul 27; cited 2016 May 8]. Carta de Gramado: Manifesto sobre o Controle do Tabagismo; [about 3 screens]. Available from: http://www.pneumoimagem.com.br/ noticia_destaque.asp?idnot $=175$

3. Doll R, Peto R, Boreham J, Sutherland I. Mortality in relation to smoking: 50 years' observations on male British doctors. BMJ. 2004;328(7455): 1519. http://dx.doi.org/10.1136/bmj.38142.554479. AE

4. Campaign for Tobacco-Free Kids [homepage on the Internet]. Washington, DC: the Campaign [cited 2016 May 8]. U.S. District Judge Gladys Kessler's Final Opinion: Summary of Findings Against the Tobacco Industry, USA, 2006 [Adobe Acrobat document, 3p.]. Available from: https://www.tobaccofreekids.org/content/what_we_ do/industry_watch/doj/FinalOpinionSummary.pdf

5. World Heath Association [homepage on the Internet]. Geneva: WHO lupdated 2005; cited 2016 May 8]. Framework Convention on Tobacco Control. [Adobe Acrobat document, 44p.]. Available from: http://whqlibdoc.who.int/publications/2003/9241591013.pdf

6. Instituto Nacional do Câncer José Alencar Gomes da Silva (INCA) [homepage on the Internet]. Rio de Janeiro: INCA; c2016 [cited 2016 May 8]. Programa Nacional de Controle do Tabagismo [about 2 screens]. Available from: http://www1.inca.gov.br/tabagismo

7. Instituto Nacional do Câncer José Alencar Gomes da Silva (INCA) [homepage on the Internet]. Rio de Janeiro: INCA; c2016 [cited 2016 May 8]. Observatório da Política Nacional de Controle do Tabaco [about 2 screens]. Available from: http://www.inca.gov.br/ observatoriotabaco/

8. Aliança de Controle do Tabagismo (ACT) [homepage on the Internet] São Paulo: ACT [cited 2016 May 8]. Tabagismo [about 2 screens]. Available from: http://www.actbr.org.br/tabagismo/

9. Associação Médica Brasileira; Ministério da Saúde/Instituto Nacional de Câncer José Alencar Gomes da Silva; Aliança de Controle do Tabagismo. Evidências Científicas sobre Tabagismo para Subsídio ao Poder Judiciário [monograph on the Internet]. São Paulo: Associação Médica Brasileira; 2013 [cited 2016 May 8]. [Adobe Acrobat document, 185p.]. Available from: http://S/evidencias_cientificas_ sobre_tabagismo_para_subsidio_ao_poder_judiciario/files/assets/ common/downloads/publication.pdf

10. Benowitz NL. Pharmacology of nicotine: addiction and therapeutics Ann Rev Pharmacol Toxicol. 1996;36:597-613. http://dx.doi. org/10.1146/annurev.pa.36.040196.003121

11. Corrêa da Silva LC, coordenador. Tabagismo. In: Pneumologia:
Princípios e Prática. Porto Alegre: Artmed; 2011.

12. World Health Organization [homepage on the Internet]. Geneve: WHO c2016 [cited 2016 May 8]. Global Status Report on noncommunicable diseases 2014. [Adobe Acrobat document, 302p.]. Available from: http://apps.who.int/iris/bitstream/10665/148114/1/9789241564854_ eng.pdf

13. Asma S, Song Y, Cohen J, Eriksen M, Pechacek T, Cohen N, et al. CDC Grand Rounds: global tobacco control. MMWR Morb Mortal Wkly Rep. 2014;63(13):277-80.

14. Lightwood JM, Glantz SA. Declines in acute myocardial infarction after smoke-free laws and individual risk attributable to secondhand smoke. Circulation. 2009;120(14):1373-9. http://dx.doi.org/10.1161/ CIRCULATIONAHA.109.870691

15. Magnus MC, Håberg SE, Karlstad $\varnothing$, Nafstad P, London SJ, Nystad W. Grandmother's smoking when pregnant with the mother and asthma in the grandchild: the Norwegian Mother and Child Cohort Study. Thorax. 2015;70(3):237-43. http://dx.doi.org/10.1136/ thoraxjnl-2014-206438

16. Carter BD, Abnet CC, Feskanich D, Freedman ND, Hartge P, Lewis $\mathrm{CE}$ et al. Smoking and mortality--beyond established causes. $N$ Engl J Med. 2015;372(7):631-40. http://dx.doi.org/10.1056/ NEJMsa1407211

17. Escola Nacional de Saúde Pública Sergio Arouca (ENSP) [homepage on the Internet]. Rio de Janeiro: ENSP [updated 2015 Jul 9; cited 2016 May 8]. Lançado o Relatório da OMS sobre a Epidemia Global de Tabagismo 2015; [about 3 screens]. Available from: http://www. ensp.fiocruz.br/portal-ensp/informe/site/materia/detalhe/38099

18. Brasil. Ministério da Saúde. Instituto Nacional de Alimentação e Nutrição. Pesquisa Nacional sobre Saúde e Nutrição (PNSN) 1989 - Arquivo de Dados da Pesquisa. Brasília: INAN/Ministério da Saúde; 1990

19. Brasil. Ministério da Saúde. Instituto Brasileiro de Geografia e Estatística (IBGE) [homepage on the Internet]. Rio de Janeiro: IBGE [cited 2016 May 8]. Pesquisa nacional de saúde 2013: acesso e utilização dos serviços de saúde, acidentes e violências-Brasil, grandes regiões e unidades da federação. [Adobe Acrobat document, 104p.]. Available from: http://biblioteca.ibge.gov.br/visualizacao/ livros/liv94074.pdf

20. Herzog B, Gerberi J, Scott A; Wells Fargo Securities. "Tobacco Talk"--Q4 U.S. Vapor Retailer Survey Company [monograph on the Internet]. San Francisco: Wells Fargo Securities LLC; 2014 [cited 2016 May 8]. [Adobe Acrobat document, 18p.]. Available from: http:// www.ecigarette-politics.com/files/4q14-wells-fargo.pdf

21. World Health Organization. Geneva: World Health Organization Report on the global Tobacco Epidemic 2008: The MPOWER package; 2008. 
22. Brecher E, van Walbeek C. An Analysis of Cigarette Affordability [monograph on the Internet]. Paris: International Union Against Tuberculosis and Lung Disease; 2008 [cited 2016 May 8]. [Adobe Acrobat document, 36p.]. Available from: http://global. tobaccofreekids.org/files/pdfs/en/TAX_Cigarette_affordability report_en.pdf

23. Fiore MC, Jaén CR, Baker TB, Bailey WC, Benowitz NL, Curry SJ, et al. Clinical practice guideline. Treating tobacco use and dependence: 2008 update [monograph on the Internet]. Rockville: US Department of Health and Human Services; 2008. [cited 2016 May 8]. [Adobe Acrobat document, 276p.]. Available from: http://bphc.hrsa.gov/ buckets/treatingtobacco.pdf

24. Viegas CAA, editor. Tabagismo: do diagnóstico à Saúde Pública. São Paulo: Atheneu; 2007.

25. Sociedade Brasileira de Pneumologia e Tisiologia (SBPT); Araújo AJ editors. Manual de Condutas e Práticas em Tabagismo. São Paulo: Gen/AC Farmacêutica; 2012

26. Reichert J, Araújo AJ, Gonçalves CM, Godoy I, Chatkin JM, Sales MP, et al. Diretrizes para cessação do tabagismo da SBPT: 2008. J Bras Pneumol. 2008;34(10):845-80. http://dx.doi.org/10.1590/S180637132008001000014

27. Cassell M, Jackson C, Cheuvront B. Health communication on the Internet: an effective channel for health behavio change? J Health Commun. 1998;3(1):71-9. http://dx.doi. org/10.1080/108107398127517

28. Oliveira F, Sales MP, Fonteles J, Silva N, Pereira F, Melo J, et al Apresentando o TratBem: Suporte Social, Informacional e Psicológico ao Tabagista. Proceedings of the 15th Workshop de Informática Médica, XXXV Congresso da Sociedade Brasileira de Computação; 2015 Jul 20-23; Recife, Brasil.

29. Oliveira F. From quitlines to smartphones: a new paradigm? Anales del $4^{\circ}$ Congreso Latinoamericano y del Caribe Tabaco o Salud; 2014 Mar 26-28; San José, Republica Dominicana.

30. Sales MP, Oliveira FM. Melo JF. Promoting social, informational and social support 24/7, uniting patients, family, friends and health professionals to fight tobacco addiction. Anales del $4^{\circ}$ Congreso Latinoamericano y del Caribe Tabaco o Salud; 2014 Mar 26-28; San José, Republica Dominicana.

31. Fletcher $\mathrm{C}$, Peto $\mathrm{R}$. The natural history of chronic airflow obstruction.
Br Med J. 1977;1(6077):1645-8. http://dx.doi.org/10.1136/ bmj.1.6077.1645

32. Anthonisen NR, Connett JE, Murray RP. Smoking and lung function of Lung Health Study participants after 11 years. Am J Respir Crit Care Med. 2002;166(5):675-9. http://dx.doi.org/10.1164/rccm.2112096

33. Tonnesen P. Smoking cessation and COPD. Eur Resp Rev. 2013;22(127):37-43. http://dx.doi.org/10.1183/09059180.00007212

34. Godoy Id, Tanni SE, Coelho LS, Martin Rdos S, Parenti LC, Andrade LM, et al. Smoking cessation program as a tool for the early diagnosis of chronic obstructive pulmonary disease. J Bras Pneumol. 2007;33(3):282-6. http://dx.doi.org/10.1590/S180637132007000300009

35. Rigotti NA. Smoking cessation in patients with respiratory disease: existing treatments and future directions. Lancet Respir Med. 2013;1(3):241-50. http://dx.doi.org/10.1016/S2213-2600(13)70063-8

36. Jiménez-Ruiz CA, Riesco Miranda JA, Altet Gómez N, Lorza Blasco JJ, Signes-Costa Miñana J, Solano Reina S, et al. Treatment of smoking in smokers with chronic obstructive pulmonary disease. Sociedad Española de Neumología y Cirugía Torácica (SEPAR) Arch Bronconeumol. 2013;49(8):354-63. http://dx.doi.org/10.1016/j. arbres.2013.02.005

37. Pinto MT, Pichon-Riviere A, Biz A, Schluckbier L, Araújo AJ. Relatório Final: Carga das doenças tabaco-relacionadas para o Brasi [monograph on the Internet]. São Paulo: Aliança de Controle do Tabagismo; 2012 [cited 2016 May 8]. [Adobe Acrobat document, 41p.]. Available from: http://actbr.org.br/uploads/conteudo/721_ Relatorio_Carga_do_tabagismo_Brasil.pdf

38. Ashraf H, Tønnesen P, Holst Pedersen J, Dirksen A, Thorsen H Døssing $M$. Effect of $\mathrm{CT}$ screening on smoking habits at 1-year follow-up in the Danish Lung Cancer Screening Trial (DLCST). Thorax. 2009;64(5):388-92. http://dx.doi.org/10.1136/thx.2008.102475

39. van Beek EJ, Mirsadraee S, Murchison JT. Lung cancer screening: Computed tomography or chest radiographs? World J Radiol. 2015;7(8):189-93. http://dx.doi.org/10.4329/wjr.v7.i8.189

40. Styn MA, Land SR, Perkins KA, Wilson DO, Romkes M, Weissfeld JL. Smoking behavior 1 year after computed tomography screening for lung cancer: Effect of physician referral for abnormal CT findings Cancer Epidemiol Biomarkers Prev. 2009;18(12):3484-9. http:// dx.doi.org/10.1158/1055-9965.EPI-09-0895 